\title{
THEATER AS A STRATEGY TO IMPROVE ORAL EXPRESSION IN EI STUDENTS OF THE KINGDOM OF SPAIN IN THE COVID-19 PANDEMIC
}

\author{
Suyo Ballarta Curin Rud ${ }^{\mathbf{1}}$, Edward Flores ${ }^{2}$ \\ ${ }^{1}$ Universidad Cesar Vallejo, ${ }^{2}$ Universidad Nacional Federico Villarreal
}

\begin{abstract}
This research formulated as the main objective of determining the influence of the theater, as a strategy on the oral expression of first grade high school students of the I.E. Kingdom of Spain, Barranco- 2020, where theories related to oral expression were considered, in turn conceptions of oral expression and its elements, are revised concept of strategies. The study was quantitative, applied type, with quasi-experimental design, the sample was intentional non-probabilistic and consisted of two groups: Control Group of 25 students and Experimental Group also of 25 first grade high school students. The technique used was observation and the instrument an Oral Expression Observation Sheet, composed of 20 items that evaluates the three dimensions worked: verbal resources, for verbal and non-verbal. The results denote positive variation in the development of oral expression before and after the implementation of the program theatre as a strategy, which changes from $92 \%$ in process to $96 \%$ as an achievement in the post test; achieving a p-value of 000, less than $\alpha$ x 0.05, by using the Mann Whitney U-test, which makes it possible to conclude that the theater program influences oral expression. It is proposed to hold theatre workshops in educational institutions to improve oral expression.
\end{abstract}

Keywords

theatre, oral expression, verbal resources, paraverbals resources, nonverbal resources.

\section{INTRODUCTION}

The human being is sociable by nature, hence the need to express what he thinks, what he feels by using oral language from the beginning of his existence arises. Language is an innate ability of the human being, which develops gradually in the course of his life, until it improves, to complement writing. That is why the importance of its study.

Internationally, it is known that all people can express themselves freely; This means that he should not be discriminated against for what he says, it gives us the possibility of making use of information and ideas, without any distinction, both orally and in writing. Children and adolescents have difficulties in communicating their ideas, feelings, opinions, which does not allow them to have an effective communication, consequently, they cannot enforce them (UNESCO 2018).

In the Instituto Educativa Reino de España de Barranco, first grade high school students have difficulties when expressing themselves orally, they cannot clearly pronounce a speech when they are in front of an audience, for fear of being criticized, they do not express their opinions and if They say it with some inconsistencies, with little use of gestures; There is not a varied use of vocabulary so it is difficult to express oneself, putting barriers to their academic, social and cultural development. It is also evident in their participation in virtual classes through the zoom and Meet tools. Therefore, the importance of working with the verbal, non-verbal and paraverbal language that is proposed in the CNEB (MINEDU, 2016).

The general objective of this work is: to determine the influence of theater, as a strategy in the oral expression of first-grade high school students of the I.E. Kingdom of Spain, Barranco- 2020 and the specific objectives are: (1) to determine the influence of theater as a strategy in the verbal resources dimension of students; (2) determine the influence of theater as a strategy in the students 'paraverbal resources dimension and (3) determine the influence of theater as a strategy in the students' non-verbal resources dimension.

Regarding the above, the following general hypothesis was raised: Theater as a strategy significantly influences the oral expression of first grade high school students of the I.E. Kingdom of Spain, Barranco - 2020 "and as specific hypotheses the following: (1) Theater as a strategy influences oral expression, verbal resources dimension, of students; (2) theater as a strategy influences oral expression, dimension of paraverbal resources, of students and (3) theater as a strategy influences oral expression, dimension of non-verbal resources, of students.

\section{MATERIALS AND METHODS}

Research type and design

This research is of an applied type, with a quasiexperimental model experimental design, with a quantitative approach. According to Hernández, Fernández and Baptista (2014) the research is applied because the objective is to solve a problem. For 
Tamayo (2012), applied or active research seeks to confront theory with reality.

Hernández, et al., (2014), pointed out that "The quantitative approach takes advantage of a set of data to test from statistical observations, and evaluate theories". Palella, (2006) mentioned that design is the strategy that the researcher assumes to solve a problem that has been formulated in a certain study. In the present study, it has an experimental design, since a variable has been manipulated, which is the theater program, which was developed with the purpose of generating changes in the dependent variable, which is oral expression.

The present study is framed in the quasi-experimental design, in which a pre-test and post-test are applied, which, according to Hernández, et al., (2014), when working with quasi-experimental designs, the research units are formed prior to the intervention, where groups cannot be separated for application. following:

The representation that corresponds to it is the

$\begin{array}{llll}\text { GE: } & 01 & \mathrm{x} & 02 \\ \text { GC: } & 03 & - & 04\end{array}$

Leyend.

GE: Experimental group

CG: Control group

$\mathrm{X}$ : Experimental theater program

$\mathrm{O} 1$ and O3: Pre test (Instrument applied to the experimental and control groups of the realization of the program).

$\mathrm{O} 2$ and O4: Post test (Instrument applied after program implementation).

The method used in the present investigation is: Hypothetical - Deductive. Rodríguez and Pérez (2017) tell us that "it is the procedure or path that the researcher follows to make his activity a scientific practice". The hypothetical-deductive method has several important steps: observation of the phenomenon to be studied, creation of a hypothesis to explain said phenomenon, deduction of consequences or propositions more elementary than the hypothesis itself, and verification or verification of the truth of the deduced statements by comparing them with the results.

\section{Variables and Operationalization}

\section{Independent variable: The theater}

\section{Conceptual definition:}

According to Huamán (1998) The theater is the representation of a play before an audience, with the purpose of entertaining. Likewise, the actor will be the protagonist who lives each moment taking into account the setting and the voice setting.

\section{Dependent variable: Oral expression}

\section{Conceptual definition:}

According to Flores (2005), oral expression consists of speaking clearly, fluently, persuasively, using verbal and non-verbal resources appropriately. In addition, it includes perceiving and understanding the ideas and messages of others in an environment of respect.

\section{Operationalization of variables and indicators}

It is the step through which the variables are divided into dimensions, then these into indicators in order to approximate the characteristics they have, in such a way that it is understandable and analyzed. Where Núñez (2007) stated that the variable is everything that is going to be measured, controlled and studied in an investigation. They can be quantitative or qualitative "

Population, sample, sampling, unit of analysis

\section{Population}

Carrasco (2009) mentioned all the elements of analysis as a population, taking into account the group of individuals who agree to develop an investigation ( $p$. 37)

The population was made up of 124 participants from the first grade of secondary school from the Kingdom of Spain Educational Institution, Barranco, UGEL O7 San Borja, 2020, located at Av. San Martín N ${ }^{\circ} 131$, Barranco, Lima-Peru.

\section{Sample}

Hernández, et al. (2014) the sample is a representative fraction of a population, from whom the data are collected. For the research, the sample is nonprobabilistic, intentional and is made up of 50 firstgrade high school students from sections A and B with 25 in each group. The sample was intended to suit the interests of the researcher and the health emergency situation that we are experiencing, since the classes are being held virtually. That is, the groups in sections A and $\mathrm{B}$ were selected because it was where the problem was identified. All students who are enrolled in the first grade at the educational institution, whose attendance and participation in classes by Meet and Zoom is greater than $75 \%$, who completed the pre and post test and the parent signed the letter of consent.

\section{Sampling}

Arias (2012) indicates non-probability sampling as a form of selection in which the probability that the 
elements of the population have to be part of the sample is unknown. The sampling is non-probabilistic for convenience, because the sample was selected according to the objective of the study.

\section{Analysis unit}

It was made up of each of the 50 research participants. Data collection techniques and instruments

Techniques

Ander - Egg (2011), technique is an operational skill in research. Hernández (2014) describes: "this stage collects the necessary data on the characteristics or variables of the units of analysis, according to the research problem". (p.198).

\section{Observation}

Carrasco (2009) defines observation as "a reliable social research technique, due to its usefulness, simplicity and objectivity of the data obtained through it." For the oral expression variable, observation was applied as a technique, using an observation sheet as an instrument applied within the hours agreed with the students, through virtual environments by video conference zoom and Meet, due to the health emergency due to COVID-19. Since we are in a remote education, by higher disposition.

\section{Instrument}

As an instrument, an observation sheet of the oral expression variable adapted from Domínguez (2019) was used and its objective is to specify the degree of oral expression of first-grade high school students. The observation file had 20 items, distributed in three dimensions. The verbal resources dimension has seven indicators and seven items. The paraverbal resources dimension contains six indicators and six items, and the non-verbal resources dimension contains seven indicators and seven items; The Likert-type scoring scale described in the operationalization table was used.

\section{Content validity}

The observation file was validated through the Judgment of Experts with research experience, so that they could make the contributions and verify if the content of the instrument is appropriate to the study. The validity results, using a format for this purpose, were obtained as "applicable"

\section{Reliability}

The reliability criterion was measured with Cronbach's alpha coefficient as it is a polytomous measuring instrument; an instrument is reliable when the coefficient is equal to or greater than 0.70 . Reliability was performed with a pilot test of 25 students out of the sample. By reliability, we understand the degree to which the observation record is consistent when measuring the variables it measures. The results obtained from 0.715 indicating that it is reliable.

\section{Procedures}

The data collection was collected from the first grade students of the I.E. Kingdom of Spain, for this the letter of introduction was sent to the director of the I.E. For its acceptance, once it was accepted, the pre-test and post-test survey was applied to both the control and experimental groups. The survey lasted 60 minutes in a virtual class on the zoom and Meet videoconferencing platform. The pre test was applied before starting the program to both groups and the post test at the end of the program.

\section{Data analysis method}

Regarding the method Rodríguez and Pérez (2017) state that "it is the procedure or path that the researcher follows to make her activity a scientific practice" (p. 151)

The process and elaboration of results was carried out with the Excel program and the statistical program SPSS version 25, using descriptive and inferential statistical methods. The distribution of data was verified with the Shapiro-Wilk test because it had a population of less than fifty. Hypothesis testing was carried out with the nonparametric Mann Whitney U test because the data distribution was not normal.

\section{Ethical aspects}

The research complied with all the standards established for the quantitative design study, likewise, the rights of the author are taken into account, for explanations and discussions, taking into account the APA standards. In addition, the instruments will be certified and established accompanied by their veracity before being applied to the sample.

The reliability of the data obtained from the participants was guaranteed, making them aware that it would be strictly academic, anonymous.

\section{RESULTS}

Descriptive analysis of the research

Table 1

Achievements obtained in the improvement of oral expression of students 


\begin{tabular}{|c|c|c|c|c|c|}
\hline & & \multicolumn{2}{|l|}{ Pre test } & \multicolumn{2}{|l|}{ Post test } \\
\hline & & Control & Experimental & Control & Experimental \\
\hline \multirow{6}{*}{ Oral expression } & \multirow{2}{*}{ Start } & 2 & 2 & 0 & 0 \\
\hline & & $8,0 \%$ & $8,0 \%$ & $0,0 \%$ & $0,0 \%$ \\
\hline & \multirow{2}{*}{ In process } & 23 & 23 & 10 & 1 \\
\hline & & $92,0 \%$ & $92,0 \%$ & $40,0 \%$ & $4,0 \%$ \\
\hline & \multirow{2}{*}{ Achievement } & 0 & 0 & 15 & 24 \\
\hline & & $0,0 \%$ & $0,0 \%$ & $60,0 \%$ & $96,0 \%$ \\
\hline \multirow{2}{*}{ Total } & & 25 & 25 & 25 & 25 \\
\hline & & $100,0 \%$ & $100,0 \%$ & $100,0 \%$ & $100,0 \%$ \\
\hline
\end{tabular}

Source: Applied instrument

\section{Figure 1}

Achievements obtained in the DV

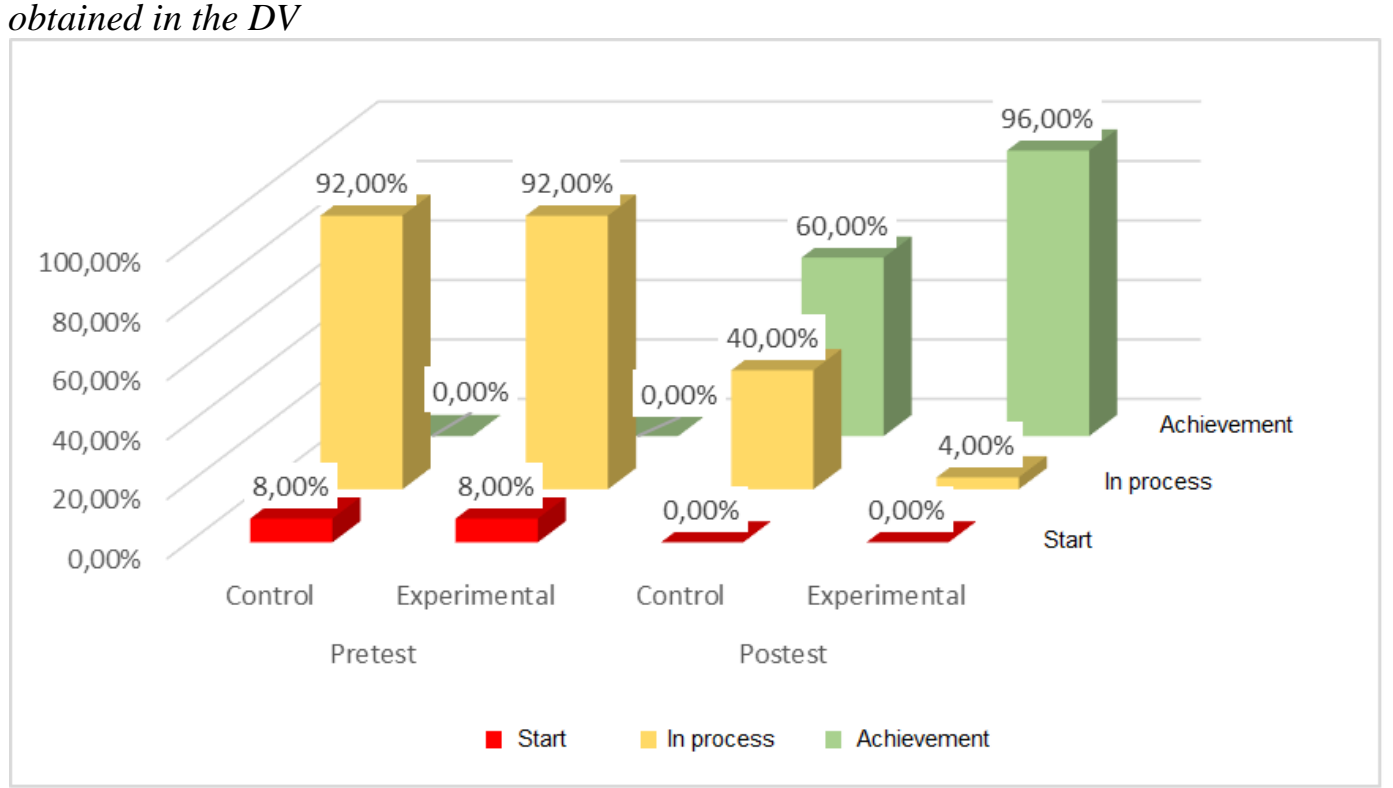

Source: Table 1

Table 2

Achievements obtained in the verbal resources dimension in students

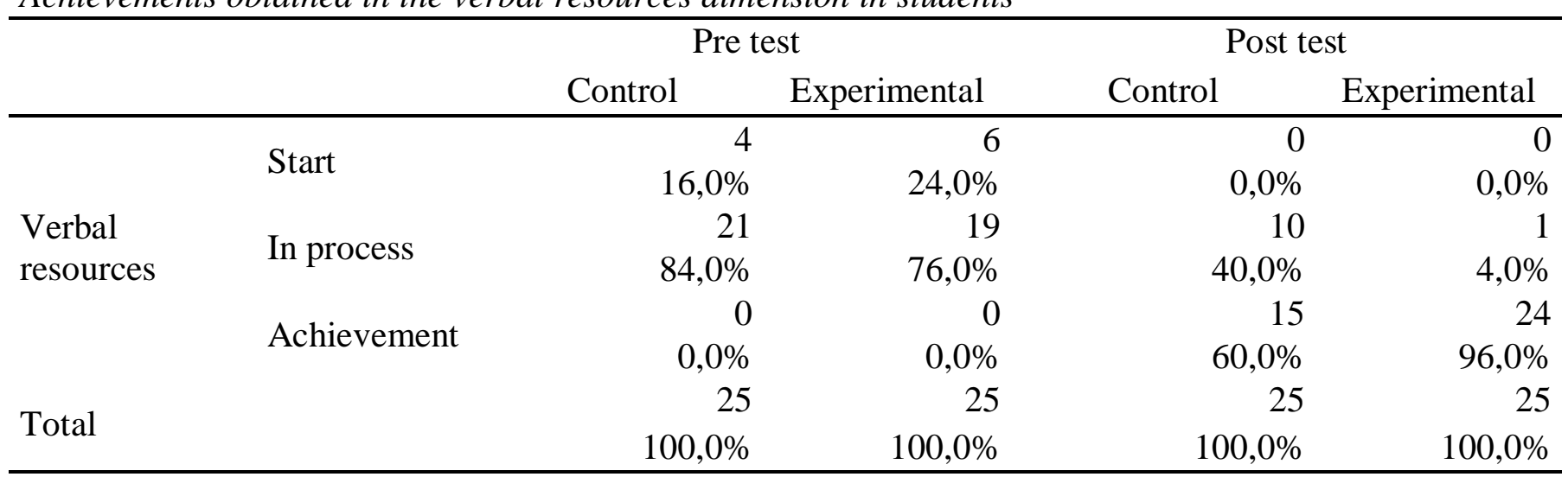

Souce: Applied instrument

\section{Figure 2}


Achievements obtained in the verbal resources dimension in students

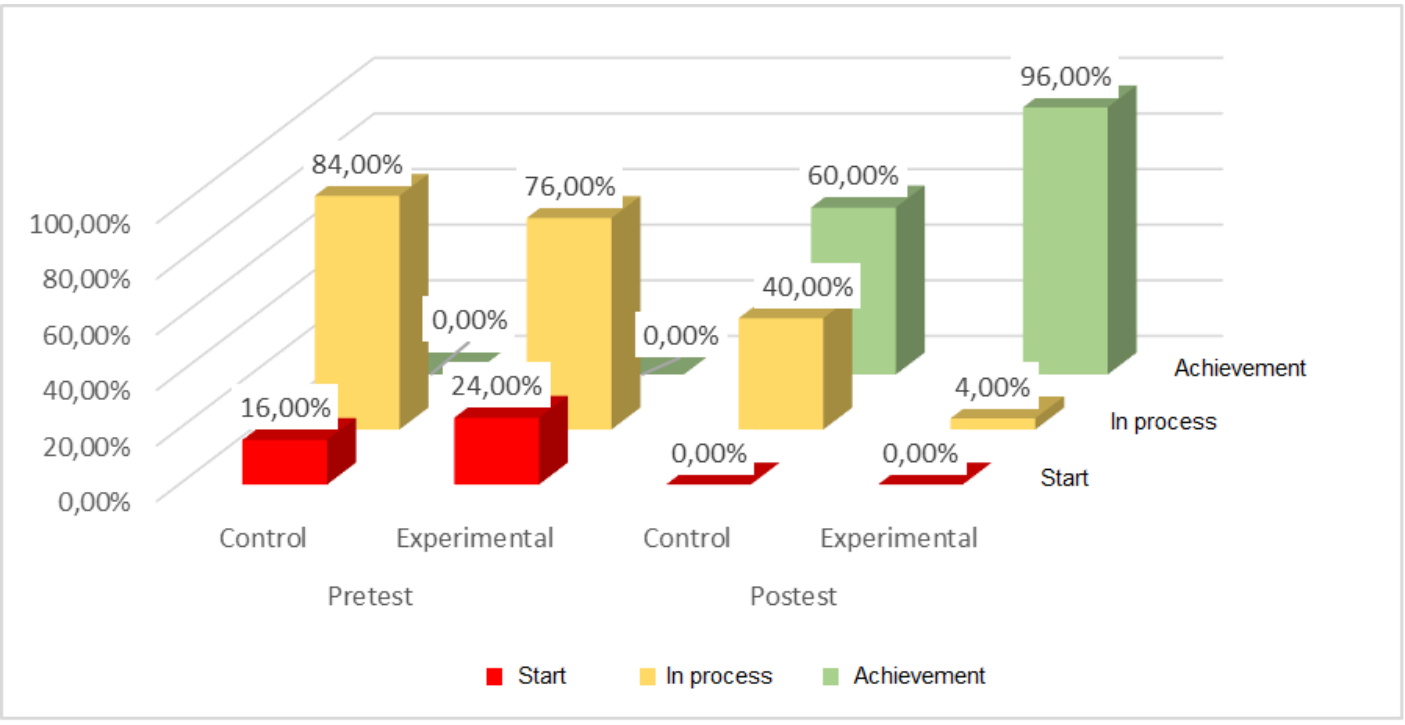

Source: Table 2

Table 3

Achievements obtained in the dimension paraverbal resources in schoolchildren

\begin{tabular}{llrrrr}
\hline & & \multicolumn{2}{c}{ Pre test } & \multicolumn{2}{c}{ Post test } \\
& & Control & Experimental & Control & Experimental \\
\hline \multirow{4}{*}{ Paraverbal resources } & \multirow{2}{*}{ Start } & 13 & 11 & 0 & 0 \\
& & $52,0 \%$ & $44,0 \%$ & $0,0 \%$ & $0,0 \%$ \\
& In process & 12 & 14 & 22 & 10 \\
& & $48,0 \%$ & $56,0 \%$ & $88,0 \%$ & $40,0 \%$ \\
\multirow{2}{*}{ Total } & Achievement & $0,0 \%$ & $0,0 \%$ & $12,0 \%$ & $60,0 \%$ \\
& & 25 & 25 & 25 & 25 \\
& & $100,0 \%$ & $100,0 \%$ & $100,0 \%$ & $100,0 \%$ \\
\hline
\end{tabular}

Souce: Applied instrument

\section{Figure 3}

Achievements obtained in the dimension paraverbal resources in schoolchildren

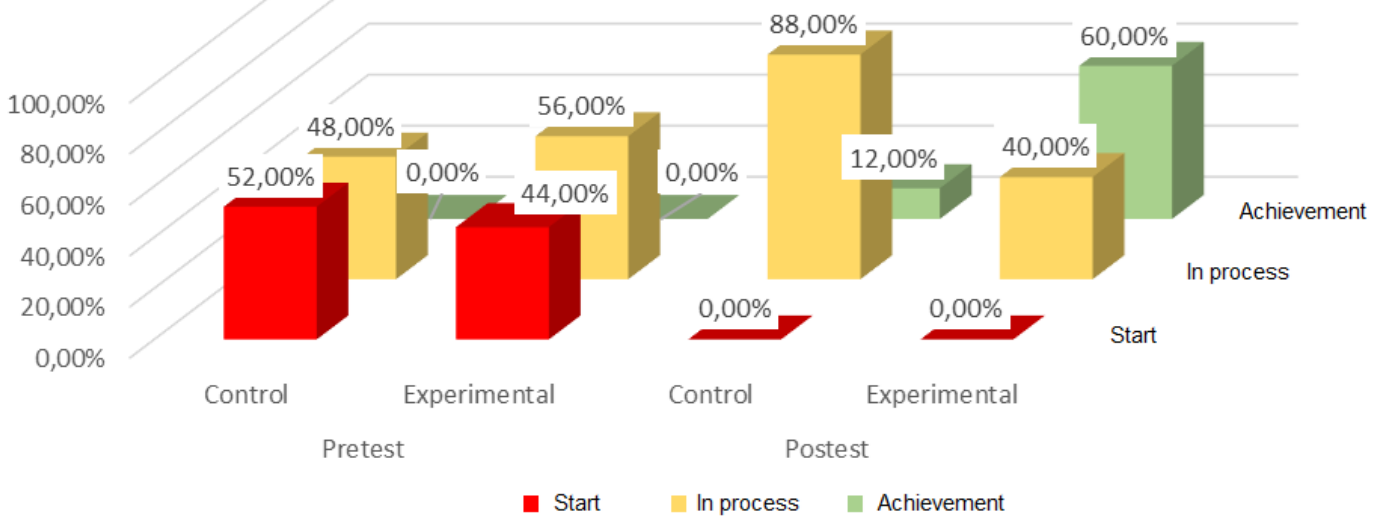

Source: Table 3

Table 4.

Achievements obtained in the non-verbal resources dimension 


\begin{tabular}{llrrrr}
\hline & & \multicolumn{2}{c}{ Pre test } & \multicolumn{2}{c}{ Post test } \\
& & Control & Experimental & Control & Experimental \\
\hline \multirow{3}{*}{ Non-verbal } & \multirow{2}{*}{ Start } & 3 & 3 & 0 & 0 \\
resources & & $12,0 \%$ & $12,0 \%$ & $0,0 \%$ & $0,0 \%$ \\
& in process & 22 & 22 & 23 & 10 \\
& & $88,0 \%$ & $88,0 \%$ & $92,0 \%$ & $40,0 \%$ \\
Total & & 0 & 0 & 2 & 15 \\
& & $0,0 \%$ & $0,0 \%$ & $8,0 \%$ & $60,0 \%$ \\
& & 25 & 25 & 25 & 25 \\
& & $100,0 \%$ & $100,0 \%$ & $100,0 \%$ & $100,0 \%$ \\
\hline
\end{tabular}

Souce: Applied instrument

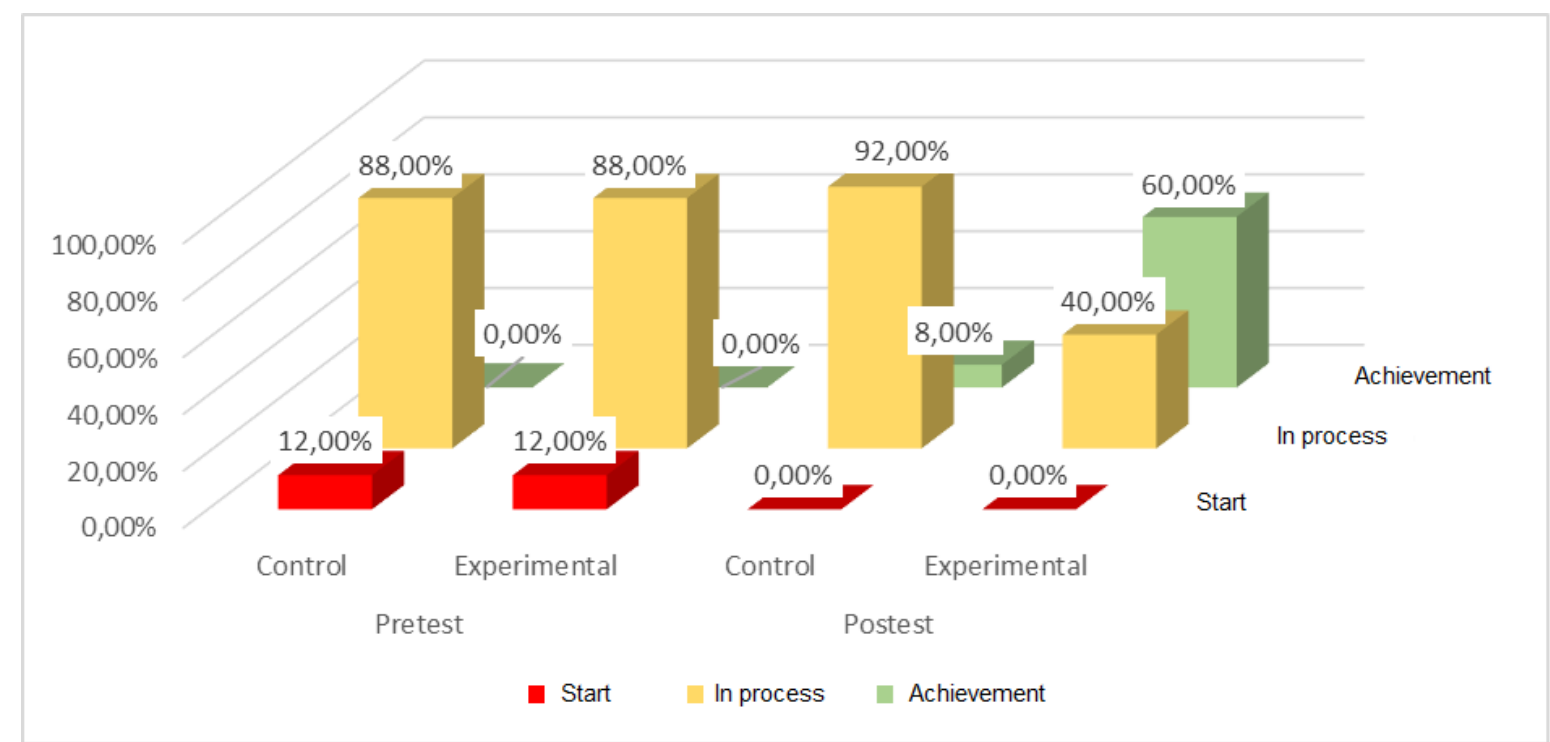

Figure 4. Achievements obtained in the non-verbal resources dimension Source: Table 4

\section{Data normality test}

Table 5.

Normality test

\begin{tabular}{llccc}
\hline \multirow{2}{*}{ Test } & & \multicolumn{3}{c}{ Shapiro-Wilk } \\
\hline Control & Pretest & Statistical & Gl & Sig. \\
& Improve oral expression &, 914 & 25 &, 038 \\
& Verbal &, 871 & 25 &, 005 \\
& Paraverbal &, 947 & 25 &, 017 \\
& Non-verbal &, 902 & 25 &, 021 \\
& Postest & & & \\
& Improve oral expression &, 919 & 25 &, 048 \\
& Verbal &, 896 & 25 &, 015 \\
& Paraverbs &, 829 & 25 &, 001 \\
& Non-verbal &, 902 & 25 &, 021 \\
Experimental & Pretest & & & \\
& Improve oral expression &, 940 & 25 &, 147 \\
& Verbal &, 895 & 25 &, 014 \\
\hline
\end{tabular}




\begin{tabular}{lccc}
\hline Paraverbs &, 942 & 25 &, 167 \\
Non-verbal &, 888 & 25 &, 010 \\
Postest & & & \\
Improve oral expression &, 948 & 25 &, 227 \\
Verbal &, 975 & 25 &, 760 \\
Paraverbs &, 961 & 25 &, 444 \\
Non-verbal &, 452 & 25 &, 452 \\
\hline
\end{tabular}

Source: SPSS vr. 25

\section{Inferential analysis}

General hypothesis

Ho $(\mathrm{Me} 1=\mathrm{Me} 2)$. The theater as a strategy does not influence the oral expression of the first grade students of the I.E. Kingdom of Spain, Barranco 2020.
Ha. $(\mathrm{Me} 1 \neq \mathrm{Me} 2)$. Theater as a strategy influences the oral expression of first grade high school students from the I.E. Kingdom of Spain, Barranco - 2020.

Table 6.

Value of the Contrast Statistic.

\begin{tabular}{lllll}
\hline Group & & Control $(\mathrm{n}=25)$ & Experimental $(\mathrm{n}=25)$ & $\begin{array}{l}\text { Test } \\
\text { U Mann-Whitney }\end{array}$ \\
\hline Pre test & & & Achievement & $\mathrm{U}=265,500$ \\
Control & Start & In process & $0,0 \%$ & $\mathrm{Z}=-0,916$ \\
Experimental & $8,0 \%$ & $92,0 \%$ & $0,0 \%$ & $p=0,360$ \\
Post test & & $92,0 \%$ & & \\
& Start & In process & Achievement & $\mathrm{U}=68,500$ \\
Control & $0,0 \%$ & $40,0 \%$ & $60,0 \%$ & $\mathrm{Z}=-4,742$ \\
Experimental & $0,0 \%$ & $4,0 \%$ & $96,0 \%$ & $\mathrm{P}=0,000$ \\
\hline
\end{tabular}

Source: SPSS v25

\section{Interpretation:}

Before the program, the groups presented similar initial conditions in their achievement levels during the pre-test with U-Mann-Whitney with $\mathrm{p}$ $=0.360>0.05$. In the post-test, both groups present significant differences in their levels of achievement with U-Mann-Whitney: $\mathrm{p}=0.000$ $<0.05$, being those of the EG those with the highest levels of achievement, as observed in the medians. It is concluded that theater as a strategy improved oral expression in first grade high school students.

\section{Specific Hypothesis Test 1.}

Ho $(\mathrm{Me} 1=\mathrm{Me} 2)$. Theater as a strategy does not influence oral expression in its verbal resources dimension in first grade high school students.

Ha. $(\mathrm{Me} 1 \neq \mathrm{Me} 2)$. Theater as a strategy influences oral expression in its dimension verbal resources in first grade high school students.

Table 7

Value of the Contrast Statistic

\begin{tabular}{llll}
\hline Group & Control $(\mathrm{n}=25)$ & Experimental $(\mathrm{n}=25)$ & Test \\
& & U Mann-Whitney \\
\hline
\end{tabular}




\begin{tabular}{lllll}
\hline Pre test & & & & \\
& Start & In process & Achievement & $\mathrm{U}=259,500$ \\
Control & $16,0 \%$ & $84,0 \%$ & $0,0 \%$ & $\mathrm{Z}=-1,052$ \\
Experimental & $24,0 \%$ & $76,0 \%$ & $0,0 \%$ & $p=0,293$ \\
Post test & & & & \\
& Start & In process & Achievement & $\mathrm{U}=92,000$ \\
Control & $0,0 \%$ & $40,0 \%$ & $60,0 \%$ & $\mathrm{Z}=-4,311$ \\
Experimental & $0,0 \%$ & $4,0 \%$ & $96,0 \%$ & $\mathrm{P}=0,000$ \\
\hline
\end{tabular}

Source: SPSS $v 25$

Interpretation: Before the program, the groups presented similar initial conditions in their achievement levels during the pre-test with UMann-Whitney with $p=0.293>0.05$. In the posttest, both groups present significant differences in their levels of achievement with U-MannWhitney: $p=0.000<0.05$, being those of the EG those with the highest levels of achievement, as observed in the medians. It is concluded that theater as a strategy influences the verbal resources of oral expression in first grade high school students.

Table 8.

Value of the Contrast Statistic.

\begin{tabular}{lllll}
\hline Group & & Control $(\mathrm{n}=25)$ & Experimental $(\mathrm{n}=25)$ & $\begin{array}{l}\text { Test } \\
\text { U Mann-Whitney }\end{array}$ \\
\hline Pre test & & & Achievement & $\mathrm{U}=271,500$ \\
& Start & In process & $0,0 \%$ & $\mathrm{Z}=-0,809$ \\
Control & $52,0 \%$ & $48,0 \%$ & $0,0 \%$ & $p=0,419$ \\
Experimental & $44,0 \%$ & $56,0 \%$ & & \\
Post test & & & Achievement & $\mathrm{U}=76,000$ \\
& Start & In process & $12,0 \%$ & $\mathrm{Z}=-4,619$ \\
Control & $0,0 \%$ & $88,0 \%$ & $60,0 \%$ & $\mathrm{P}=0,000$ \\
Experimental & $0,0 \%$ & $40,0 \%$ & &
\end{tabular}

Source: SPSS v25

Interpretation: Before the program, the groups presented similar initial conditions in their achievement levels during the pre-test with UMann-Whitney with $p=0.419>0.05$. In the posttest, both groups present significant differences in their levels of achievement with U-MannWhitney: $p=0.000<0.05$, being those of the EG those with the highest levels of achievement, as observed in the medians. It is concluded that

\section{Specific Hypothesis Contrast 2.}

Ho $(\mathrm{Me} 1=\mathrm{Me} 2)$. Theater as a strategy does not influence oral expression in its dimension paraverbal resources of students.

Ha. $(\mathrm{Me} 1 \neq \mathrm{Me} 2)$. The theater as a strategy, influences the oral expression in its dimension paraverbal resources of the students.

Ha. (Me1 $\neq \mathrm{Me} 2)$. Theater as a strategy influences oral expression in its dimension, non-verbal resources of students.

Table 9. 
Value of the Contrast Statistic.

\begin{tabular}{lllll}
\hline Gruop & & Control $(\mathrm{n}=25)$ & Experimental $(\mathrm{n}=25)$ & $\begin{array}{l}\text { Test } \\
\text { U Mann-Whitney }\end{array}$ \\
\hline Pre test & & & & $\mathrm{U}=298,500$ \\
& Start & In process & Achievement & $\mathrm{Z}=-0,278$ \\
Control & $12,0 \%$ & $88,0 \%$ & $0,0 \%$ & $p=0,781$ \\
$\begin{array}{l}\text { Experimental } \\
\text { Post test }\end{array}$ & $12,0 \%$ & $88,0 \%$ & $0,0 \%$ & $\mathrm{U}=122,000$ \\
& & & & $\mathrm{Z}=-3,716$ \\
Control & Start & In process & Achievement & $\mathrm{P}=0,000$ \\
Experimental & $0,0 \%$ & $92,0 \%$ & $8,0 \%$ &
\end{tabular}

Source: SPSS v25

Interpretation: Before the program, the groups presented similar initial conditions in their achievement levels during the pre-test with UMann-Whitney with $\mathrm{p}=0.781>0.05$. In the posttest, both groups present significant differences in their levels of achievement with U-MannWhitney: $p=0.000<0.05$, being those of the EG those with the highest levels of achievement, as observed in the medians. It is concluded that theater as a strategy influences the non-verbal resources of oral expression in first grade high school students.

\section{CONCLUSIONS}

First: It was determined that the theater program as a strategy influences $96 \%$ as the level of achievement of oral expression in the students of the Experimental G. and a p value of .000 by means of the Mann Whitney $U$ test for unrelated samples.

Second: It was determined that the theater program as a strategy influences $96 \%$ as the level of achievement in the verbal resources of oral expression in the students of the Experimental G., and a $p$ value of .000 by the Mann Whitney $U$ test for unrelated samples.

Third: It was determined that the theater program as a strategy influences the paraverbal resources of oral expression in students of the Experimental G. by $60 \%$ as an achievement level and a $p$ value of .000 by means of the Mann Whitney U test for samples not related.

Fourth: It was determined that the theater program as a strategy influences the non-verbal resources of oral expression in the students of the Experimental $\mathrm{G}$ by $60 \%$ as an achievement level and a $\mathrm{p}$ value of .000 by means of the Mann Whitney $\mathrm{U}$ test for unrelated samples.

\section{REFERENCES}

Ander - Egg, E. (2011). Aprender a investigar: nociones básicas para la investigación social. Córdoba, Argentina: Brujas.

Arias, F. (2012). El Proyecto de Investigación: Introducción a la Metodología Científica. Caracas, Venezuela. Ed. Episteme. 6ta edición. International Journal of Medicine and Pharmaceutical Sciences (IJMPS) 5.3, Jun 2015, 85-98

Carrasco, D. (2009). Metodología de la Investigación científica. Editorial San Marcos. 1ra Reimpresión 2009.

Dominguez, R. M. (2019). Programa estrategias didácticas en la expresión oral en estudiantes de quinto grado de primaria en una institución educativa del km.50 - 2019 [Tesis de maestría, Universidad César Vallejo]. In Repositorio Institucional - UCV. http://repositorio.ucv.edu.pe/handle/20.500.1 2692/46936 https://n9.cl/4ovqj

Flores, E. (2005). Expresarse con claridad, fluidez, coherencia y persuasión. Lima: Albor

Hernández, R. Fernández, C. \& Baptista, P., (2014). Metodología de la investigación. $\left(6^{\mathrm{a}}\right.$ ed.). D.F., México: Mc Graw Hill.

Huamán, D. (1998). Dramatización y títeres. México. Editorial. Trillas.

Hamadneh, Bandar, A. L. Hayder, and Malik Haddadin. "NOVEL BITTER MELON (MOMORDICA CHARANTIA L.) AND 
OLIVE LEAVES (OLEA EUROPAEA L.) PHYTOSOMES: PREPARATION AND ITS EVALUATION FOR ANTIHYPERGLYCEMIC ACTIVITIES BY ORAL GLUCOSE TOLERANCE TEST (OGTT)." International Journal of Applied and Natural Sciences (IJANS) 7.3, Apr - May 2018; 31-40

Ministerio de Educación (2016). Currículo Nacional de la Educación Básica. Lima: Perú.

Núñez, M. (2007). Las Variables: estructura y función en la hipótesis. Investigación educativa. 11 (20), 163-179.

Okeke, Evelyn Nkiruka, Joseph Uchenna Okeke, and Adashu Daniel. "Multivariate Analysis of Variance of University Students' Academic Performance." International Journal of Applied Mathematics \& Statistical Sciences (IJAMSS) ISSN (P) (2018): 23193972.

Palella, S., \& Martins, F. (2006). Metodología de la investigación cuantitativa. FEDUPEL. $3^{\mathrm{a}}$. Edición.

https://es.calameo.com/read/000628576f5173 2890350

Rodríguez , A., y Pérez, A. O. (2017). Métodos científicos de indagación y de construcción del conocimiento. Escuela de Administración de Negocios, (82), 1-27. doi: https://n9.cl/5kab5

Tamayo, M. (2012) "El proceso de la investigación científica" México Editorial Limusa S.A. de C.V.

THANGARAJ, K., and M. KALPANA. "AN EVALUATIVE STUDY OF THE ORAL SKILLS OF UNDERGRADUATE AGRICULTURAL STUDENTS OVER THEIR ENTRY LEVEL." International Journal of Educational Science and Research (IJESR) 10. 4, Aug 2020, 31-40

UNESCO. (2018). Tendencias mundiales en libertad de expresión y desarrollo de los medios: UNESCO/MEC. Informe mundial.171-201 https://n9.cl/z1n2m 